\title{
Precarious Employment in the Chilean English Language Teaching Industry
}

\author{
Lasekan Olusiji Adebola ${ }^{1, *}$, Moraga Ana ${ }^{2}$, Quezada Claudia ${ }^{3}$, Alvarez Boris ${ }^{4}$ \\ ${ }^{1}$ Departamento de Educación Media, Universidad Catolica de Temuco, Temuco, Chile \\ ${ }^{2}$ Facultad de Ciencias Juridicas y Empresariales, Universidad de La Frontera, Temuco, Chile \\ ${ }^{3}$ Facultad de Ciencias Sociales y Humanidades, Universidad Catolica de Temuco, Temuco, Chile \\ ${ }^{4}$ Núcleo de Ciencias Sociales y Humanidades, Universidad de La Frontera, Temuco, Chile
}

Received March 28, 2020; Revised September 18, 2020; Accepted October 19, 2020

\section{Cite This Paper in the following Citation Styles}

(a): [1] Lasekan Olusiji Adebola, Moraga Ana, Quezada Claudia, Alvarez Boris, "Precarious Employment in the Chilean English Language Teaching Industry," Universal Journal of Educational Research, Vol. 8, No. 11B, pp. 6000 6013, 2020. DOI: 10.13189/ujer.2020.082236.

(b): Lasekan Olusiji Adebola, Moraga Ana, Quezada Claudia, Alvarez Boris (2020). Precarious Employment in the Chilean English Language Teaching Industry. Universal Journal of Educational Research, 8(11B), 6000 - 6013. DOI: 10.13189/ujer.2020.082236.

Copyright $\bigcirc 2020$ by authors, all rights reserved. Authors agree that this article remains permanently open access under the terms of the Creative Commons Attribution License 4.0 International License

\begin{abstract}
This study investigates the degree of precarious employment in the Chilean English language teaching industry. We recruited a random sample of two hundred and twenty-three English teachers from the primary and secondary schools, Universities, as well as Private English Institutes through an online survey. A cross-sectional study of the socio-demographic variables of precarious employment was conducted through the analysis of proportional variances according to gender, age, school curriculum, educational qualification, and teaching status. Nine indicators represented the six dimensions of the Employment Precariousness Construct were adopted for the measurement. The results revealed that the majority $(56.8 \%)$ of English teachers have temporary contracts. Although the degree of precariousness was higher in dimensions comprising temporariness, wages, rights, and the exercise of rights, vulnerability among teachers holding temporary contracts compares with those possessing permanent contracts, there was no significant difference between the two groups concerning the dimension of disempowerment. Overall, our results showed that the level of precarious employment in the industry is moderately low. Implications of the results and future research directions are presented.
\end{abstract}

Keywords Precarious Employment, English Language Teaching, Chile, Industry

\section{Introduction}

Taking into account the multidimensional complexity of precarious employment (Jain, 2014), European Study on Precarious Employment (ESCOPE) describes the term as employment that includes impermanent employment, on-call work, quasi self-employment, underemployment created under socially accepted normative standards (themes related to rights, legislation on employment protection, and of collective protection) (Frade, Darmon, \& Laparra, 2004). The authors state that the dimensions of precarity stem from an unequal distribution towards and amongst employees. They believe that such imbalances consequently lead to the segmentation of labor, which in turn exacerbates job insecurity. The causes of precarity have been linked to a global increase in flexible job relations and there is a growing trend toward making employment more flexible (Arnold \& Bongiovi, 2013). This malaise manifests itself through new employment forms marked by higher levels of job insecurity and an overall depletion of workers' employment (Lewchuk, 2016), and working conditions (Quinlan, 2016). Precariousness has also been used by public health experts as a social determinant of community health problems, given the negative effect of precarious work on public well-being (Benach \& Muntaner, 2007). Several studies have reported on its prevalence in the educational sector (Simbürger \& Neary, 2016: Lopes \& Dewan, 2014). A 
temporary contract is the most prevalent form of an employment contract in Europe, and the educational sector accounts for $15 \%$ of all industries (European Foundation for the Improvement of Living and Working Conditions, 2006). Its pervasiveness in higher education in England (UCU, 2016) and Canadian schools (Mindzak, 2016) have been mentioned. Chilean education is also not immune to this problem. As of 2015, university lecturers working as casual staff in Chilean universities are up to $75 \%$ (Berrios, 2015). Concerning English language education, a subset of general education, Wickam (2015) describes the deteriorating working condition under which English teachers work in France. In his seminal study, only $11.5 \%$ of English teachers have full-time permanent contracts while the rest have zero-hour contracts, fixed-term contracts, and independent workers with no contract. The problem, which is gaining much attention among the Chilean English teaching community on different social media platforms, has led to the formation of a social group advocating for the positive change in the narrative of precarity in the ELT industry. To provide empirical evidence to the issue and open a new vista of academic discussion in Chilean ELT research, we seek to investigate the degree and pattern of precariousness employment in the Chilean ELT industry. Data for this study were collected using the Chilean version of The Employment Precariousness Scale (EPRES) (Vives et al., 2010). The paper begins by laying out the theoretical dimensions of the research, followed by the methodology, after that, result, then discussion, and finally, a conclusion where a summary and critique of the findings are given.

\section{Literature Review}

The beginning and development of precarity as a concept in academic literature commenced in the $70 \mathrm{~s}$ (Barbier, 2002). Since then, its theoretical view has been based on two strands (McCormack \& Salmenniemi, 2016). The first strand is on the tenet of vulnerability as an existential condition of humanity (Butler, 2004b). That is, precarity is part of life itself. On the other hand, the second strand argues that the manifestation of precarity is a result of labor, subjective, and contemporary capitalism as well as neoliberalism on life (McCormack \& Salmenniemi, 2016). The second strand appears to be more profound in academic literature because of its relevance in socio-scientific discourse (Neilson \& Rossiter, 2008), especially in contemporary economic and social life (Standing, 2011). One key paradigmatic feature of precarity is labor conditions (Bourdieu, 1998: Berlant, 2011). The dimension of this precarity includes job security, temporary or part-time employment, inadequate welfare benefits, and low salaries (Millar, 2017). The neoliberalism policy adopted by most governments has been reported to cause precarity. The causal effect has been based on the understanding of the role of power under neoliberalism and the role that precarity plays in domination propounded by Focualt in 2008 (as cited in Masquelier, 2019). Foucault 2008:145 argues that the neoliberalism policy of several States can compel individuals to become self-entrepreneur by promoting competition through the withdrawal of welfare packages, unjust regulation, and privatization. Such entrepreneur subjectivity of the society exacerbates precarity because individuals are controlled to experience their situation, their life, their present, and their future as containing danger (Focualt 2008, p. 66). In other words, neoliberalism is expected to result in a shift in time, a move towards thinking of life as a series of ventures, where an individual can be optimistic about the future. Still, the present is a set of self-regulatory processes that are supposed to activate the prospect (and fantasy) of one day not being vulnerable (McCormack \& Salmenniemi, 2016). In sum, all these theoretical dimensions of precariousness are vital in interpreting how precarity is manifested in the ELT industry.

Numerous studies on the connection between precarity and work stress rise from the need to understand employees' attitudes and behavior towards the organization (Colak, 2015; Bhandari \& Hesmati 2006). Some argue that the variance in employees' attitudes and behavior depends on the nature of the Psychological Contract (PC) that occurs between the employee and employer (Colak, 2015). The term is defined as a set of reciprocal expectations held by employees concerning their duty and entitlement (McLean, Parks, Kidder, \& Gallagher, 1998: 698). The authors point out that the type of PC that employees create with their employer affects how they perceive different factors related to their working environment. These determinants are work stress and the theory of social comparison and social exchange. For example, an employee can feel work stress when they considered themselves less critical in an organization and that their organization is less likely to invest in them in terms of salaries (Bhandari \& Hesmati 2006), promotion (Zeytinoglu et al., 2004) and training opportunities (Connelly and Gallagher 2004). Furthermore, an employee can link their stress level to a small amount of influence on workplace decisions (Aronson et al., 2002) and little support they receive from their co-worker (Byoung-Hoo \& Frenkel, 2004). The third determinant of employee work stress can be linked to employment strain (Lewchuk et al., 2005). According to the author, the connection occurs when an employee is spending more time in searching for new employment while attempting to keep current employment by seeking positive employer assessment of work and uncertainty with regard to the terms and conditions of employment and one's future job. Contrarily, theory on social comparison and social exchange state that employees' work stress can be connected to any experience of unfairness (Colak, 2015). Such a feeling of unfairness occurs among employees whose organization does not have an effective mechanism that rewards good performance. With respect to 
employment in education, several attempts have been made to assess the impact of temporary jobs on their affective conditions. The feeling of uncertainty, powerlessness, and marginalization that teachers face in schools have been recorded (Jenkins, Charteris, Bannister-Tyrrell \& Jones, 2017). This can be connected to fear and anxiety (McCormack, A., \& Thomas, K. 2005). Available study in Chile focuses on the link between work stress and job demands (Quiñones, Van den Broeck \& De Witte, 2012). The gap in the body of literature is the link between job insecurity and work stress among English teachers.

Many experts have investigated precarity among the Chilean teaching workforce. Simbürger and Neary (2016) coined the word "taxi professors" as a metaphor to label academics who work on an hourly basis, teach at different universities and rush from one location of work to the next. Between 2005 and 2011, the number of academic staff working hourly rose from $67 \%$ to $75 \%$ (Berreos, 2015 ). In several contexts, its ubiquitous nature and its adverse effect among academics in Ireland (Courtois \& O'Keefe, 2015) and Australia (Percy \& Beaumont, 2008) have also been noted. Except for the work of Mindzak (2016), conducted among Canadian teachers working within K-12 settings, it appears most scholars are more interested in precarity in higher education. Regarding the English language teaching industry (ELT), attention has been called into the need to investigate precarity in the industry (Walsh, 2019). The only documented study in this regard was conducted in France (Wicham, 2015). A variance of variables was investigated and quantified. This ranges from the number of teachers with qualifications, types of work contracts, and private tuition fees charged by teachers, amongst others. It is reported that $11.5 \%$ have full-time contracts, while those with zero-hour contracts account for $14 \%$ of the industry. Thus, in response to Walsh (2019) on the need for more research on precarity in ELT in different EFL contexts, it will be interesting to know the degree and pattern of precarity in the Chilean English teaching industry.

The EPRES scale is an instrument developed to carry out epidemiological studies among wages and salaried workers in the different labor markets. The employment precariousness construct was conceptualized and operationalized by Amable et al. (2006). The six-dimension construct includes instability of employment/temporary low earning, inadequate workplace rights, social protection, the capacity to help workers in exercising their rights and benefits they are entitled to, the absence of collective bargaining over employment and working conditions and vulnerability. Over the years, the scale has been validated and used to measure precarity among salaried workers in Spain (Vives et al., 2010), workers in various industries in Europe (Puig-Barrachina et al., 2014) and different industrial sectors in Chile (Vives-Vergara et al., 2017). The gap in the literature is the use of the instrument to assess precarity in the Chilean educational sector.

Against this backdrop, no research has been found that surveyed the degree and pattern of precarity in the ELT industry. Investigating such a concept in an ELT industry can be construed differently from different perspectives. To some, the word "industry" can be associated with efficacy, productivity, privatization, marketization, consumerism, digitalization of education rather than public service provided by the State (Kerr \& Wickham, 2017). Perhaps upholding the latter's view can be used to explain the training and supplying of pre-service English teachers to only elementary and secondary schools. Thus, we hypothesize that the oversupply of teachers to this particular jurisdiction can exacerbate precarious employment in the mainstream schools. However, the demand and service of ELT cannot be confined to mainstream education (Lasekan, 2019). Therefore, we adopt the term "industry" to accommodate English teachers working in private English institutes and other spaces where English teachers offer their services.

\section{Methodology}

\section{Research Design}

The current study investigates the degree of job precarity among English teachers and their impact on their well-being in the ELT industry. The findings could be valuable to English teachers who are searching for a job or trying to negotiate a job contract. A questionnaire was adopted to collect quantitative data to examine the informants' dimension of precarity. Also, interviews with selected participants provided qualitative data for further understanding of their degree and pattern of precarity among the teachers. Employing two instruments is necessary because interpretations that are built upon triangulation have a higher tendency to be stronger than those reliant on the more constructed framework of a single method (Lincoln \& Denzin, 2000). Therefore, this study used concurrent mixed methods to elicit quantitative and qualitative data. After the data collection, all the information was integrated and interpreted (Creswell, 2009, p. 14).

\section{Research Site, Population, and Sampling}

This study adopted a random sampling technique in which a smaller sample size is culled from a larger population and uses it to research and make generalizations about the larger group (Banerjee and Chaudhury, 2010). Our choice was based on the simplicity of the technique (Taherdoost, 2016). However, to understand how different groups of participants view our precarity so that their perspectives can be as representative as possible, we adopted maximum variation sampling (List, 2004). As shown in Table 1, all the informants $(n=223)$ are English teachers from different regions of Chile. It is a composition of teachers working in elementary schools (public), elementary schools (subsidized), elementary schools 
(private) secondary schools (public), secondary schools (subsidized), secondary schools (private), university (public), university (subsidized), university (private) and English institutes.

\section{Research Instrument}

Questionnaire: The purpose of the questionnaire was to collect quantitative data that would reveal the level of precarious dimensions such as temporariness, disempowerment, vulnerability, wages, rights, and exercise rights. The items in the questionnaire were drawn from various existing inventories designed to measure precarity in different industries (Vives et al., 2010; Amable, 2009). By adopting face validity, we assumed that the instrument for this study is valid because each item addresses the specific and relevant aspects of perceived motivation, attitude, and cultural awareness (Holden, 2010). Moreover, a pilot questionnaire was administered to 12 participants. This was conducted to get their feedback on the accuracy, clarity, and cultural appropriateness of all items in the translated questionnaire. Items were validated based on errors of language equivalence noticed by Spanish-English translators and statistical experts. The questionnaire was divided into four sections. The first part of the questionnaire deals with respondents' demographic profiles such as age, gender, level of education, and years of teaching experience after graduation. While the second part consists of 4 closed questions that focus on participants' past and current teaching status while the third and fourth questions deal with the perception of factors influencing precarious employments in ELT industry. The history and current teaching status scale are made up of items that determine teachers' past and current status of the employment contract. This study considered four items that focus on the level of curriculum that is taught, last year's teaching status, the prospect of a job offers for the next teaching period, and the type of contract offer that is received. The items are adapted from a questionnaire used to determine teachers' eligibility for employment insurance benefits in Canada (Employment insurance, 2011)

To ascertain the degree of precarious employment in ELT, we adopted the EPRES questionnaire developed by Amable (2009). It consists of six subscales: 'disempowerment' (level of negotiation of work conditions) (3 items); 'temporariness' (contract period) (2 items); 'wages' (low or insufficient; potential economic deprivation) (3 items); 'vulnerability' (defenselessness to authoritarian treatment) (5 items); 'exercise rights' (powerlessness, in practice, to exercise workplace rights) (5 items) and 'rights' (entitlement to labor rights and social security benefits) (7 items). Response scales consist of a 5 -point frequency scale in the 'vulnerability' and 'exercise rights' subscales; 5-point ordinal scales in 'wages' and 'temporariness'; and 3-point categorical scales in the 'disempowerment' and 'exercise rights' subscales. We followed Amable (2009) approach by computing subscale scores as simple averages and converted them into a 1-5 scale, with high values representing low levels of precariousness and vice versa. The overall EPRES score, ranging from 5 (not precarious) to 1 (most precarious), is the arithmetic mean of the six subscale scores. Calculated in this way, each subscale contributes equally to the total score, regardless of its number of items [25].

Section 4 is a Five-point Likert scale ranging from strongly agree to strongly disagree with eliciting respondents' views on the evaluation of teachers as part of teachers' rehiring process, the effect of employment contracts in making long-term plans and financial commitment, teachers' interest in their profession and lev stress level.

Based on the pattern of the quantitative analysis, a focus group was created to provide fresh perspectives to the interpretation of the data. The group consists of two teachers in primary school, two teachers in secondary, two teachers in the university, a former vice-rector undergraduate of a university, and a principal of a school. The close-ended questions centered around teachers' views on factors influencing precarity in the industry, the role of the employer in alleviating the problem, the importance of students' evaluation of teachers as a metric for rehiring them, and decision making in relation to the settlement of employment conditions. The obtained data provided by the participants were analyzed using qualitative thematic analysis to answer the questions and accomplish the objective of this study. Our data was manually-coded. We adopted the inductive coding. This involves categorizing opinions into common themes (Cooper et al., 2012). The themes that emerged were used to address issues related to the core objectives under investigation.

\section{Data Collection and Analysis}

Data for this study were retrospectively collected through an anonymous online survey. The data were administered and obtained between January and February 2020. Thus, this study's report can be regarded as precarious employment of the previous year (2019). All research ethics codes for data collection, which involves explaining the objective of the study to the informants, informing of the right to decline to participate, and explaining the low potential risk involved by providing the greatest sense of respondent confidentiality were upheld.

Collected data were analyzed through SPSS v25.0. The demographic distribution of precarious employment was obtained through the analysis of the proportions of English teachers within the precarious employment indicators according to age, educational qualification, gender school curriculum amongst others (Table 1). The overall mean score of the EPRES (6 dimensions) was assessed. The Kolmogorov-Smirnov test revealed that the study variables violate the univariate normality assumption $(p>.05)$, therefore we used a non-parametric test. For independent group differences, such as age, gender and types of contract, we used Mann-Whitney U test (2 groups) as well as Kruskal-Wallis test (3 or more groups). In addition, 
Mann-Whitney test was also used as a nonparametric Post hoc alternative to compare each pair of groups (Hernandez, Fernandez \& Baptista, 2010). The validity was also tested by calculating the reliability of the items adopted in the instrument through Cronbach's alpha for the total scale and for each dimension.

\section{Result}

The demographic and occupational characteristics of study participants are presented in Table 1 . The sample includes a higher proportion of female English teachers
$(81.2 \%)$ than men $(18.8 \%)$, with over $64 \%$ of the sample living in the Central region of the country. Except at the university level, the majority of the informants work in subsidized Primary schools (56\%) and Secondary schools (41\%). Permanent contracts holders stand at $(44.2 \%)$, followed by temporary contracts $(29 \%)$, then by 10 months' contracts teachers $(11.6 \%)$, and finally by those workings as a substitute $(6.3 \%)$, combination of casual, substitute and period of contracts (5.4\%) and casual teachers (3.6\%). Furthermore, many of the respondents considered for this study have a Bachelor degree.

Table 1. Sociodemographic characteristics of the study sample

\begin{tabular}{|c|c|}
\hline Variables & n (\%) \\
\hline \multicolumn{2}{|l|}{ Sex } \\
\hline Male & $42(18.8)$ \\
\hline Female & $181(81.2)$ \\
\hline \multicolumn{2}{|l|}{ Age } \\
\hline$<30$ & $76(34.1)$ \\
\hline $30-55$ & $135(60.5)$ \\
\hline$>55$ & $12(5.4)$ \\
\hline \multicolumn{2}{|l|}{ Chilean Geographical Location } \\
\hline North & $18(8.1)$ \\
\hline Center & $140(62.8)$ \\
\hline South & $65(29.1)$ \\
\hline \multicolumn{2}{|l|}{ Years of Teaching Experience } \\
\hline$<10$ & $147(65.9)$ \\
\hline $10-20$ & $59(26.5)$ \\
\hline $21-30$ & $11(4.9)$ \\
\hline$>30$ & $6(2.7)$ \\
\hline \multicolumn{2}{|l|}{ Maximum Qualification } \\
\hline TELF certificate & $19(8.5)$ \\
\hline Bachelor & $149(66.8)$ \\
\hline Master & $51(22.9)$ \\
\hline $\mathrm{PhD}$ & $4(1.8)$ \\
\hline \multicolumn{2}{|l|}{ Educational level } \\
\hline \multicolumn{2}{|l|}{ Primary Education } \\
\hline Public & $35(15.7)$ \\
\hline Subsidized & $56(25.1)$ \\
\hline Private & $12(5.4)$ \\
\hline \multicolumn{2}{|l|}{ Secondary Education } \\
\hline Public & $29(13.0)$ \\
\hline Subsidized & $41(18.4)$ \\
\hline Private & $8(3.6)$ \\
\hline \multicolumn{2}{|l|}{ University Education } \\
\hline Public & $10(4.5)$ \\
\hline Subsidized & $7(3.1)$ \\
\hline Private & $13(5.8)$ \\
\hline Private English Institutes & $12(5.4)$ \\
\hline \multicolumn{2}{|l|}{ Teaching Status } \\
\hline Casual on call & $8(3.6)$ \\
\hline Substitute & $13(5.8)$ \\
\hline 10-month contract & $26(11.7)$ \\
\hline Temporary contract & $65(29.1)$ \\
\hline Combination of casual/substitute with some periods under contract & $12(5.4)$ \\
\hline Permanente contract & $99(44.4)$ \\
\hline \multicolumn{2}{|l|}{ Have you received an offer of employment for 2020} \\
\hline Yes & $111(49.8 \%)$ \\
\hline No & $112(50.2 \%)$ \\
\hline \multicolumn{2}{|l|}{ What type of contract offers have you received for 2020} \\
\hline Casual & $116(36.9 \%)$ \\
\hline Substitute & $51(16.2 \%)$ \\
\hline Permanent & $147(46.8 \%)$ \\
\hline
\end{tabular}




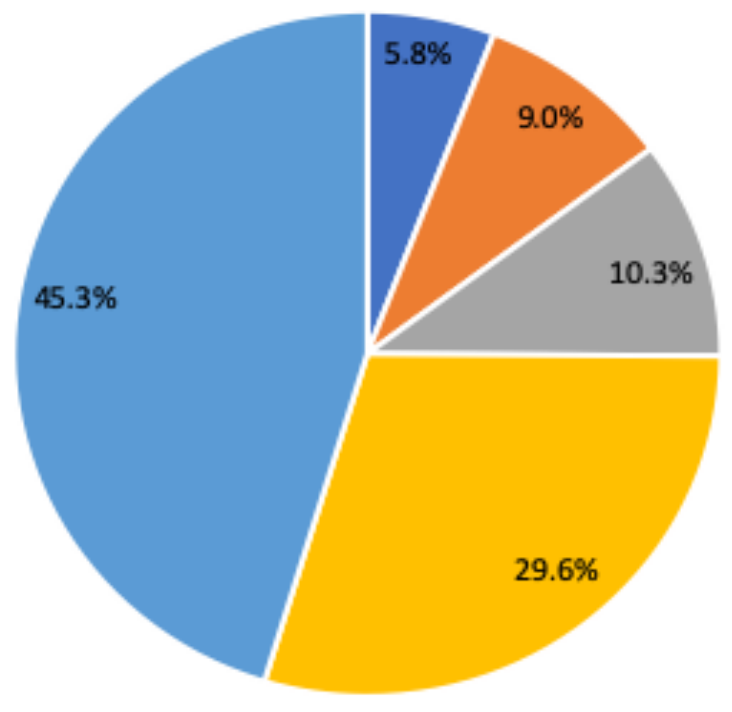

- Less than 6 months

- Between 6 and less than 12 months

= Temporary, non-fixed term

1 year or more

- Permanent contract

Figure 1. Duration of contract possess by Chilean English teachers

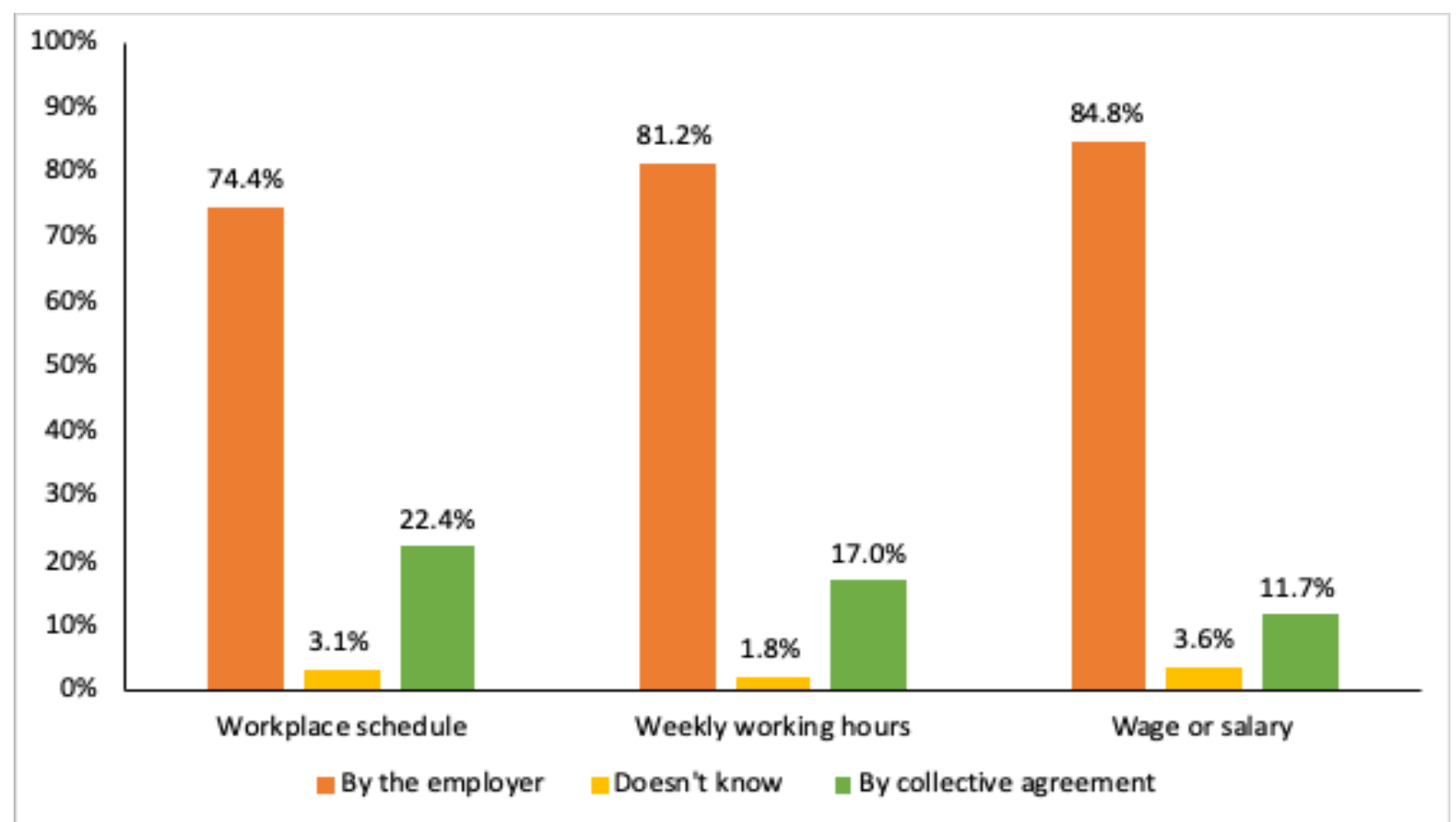

Figure 2. Perception of English teachers regarding the settling of employment condition

\section{Duration of contract}

Figure 1 shows an overview of the duration of contracts (not teaching status) possess by English teachers. It is apparent that the vast majority of teachers had a permanent contract $(45.3 \%)$. While $29.6 \%$ had one year or more in their employment contract, $10.3 \%, 9 \%$, and $5.8 \%$ said the period of their contract is a temporary but non-fixed term, between six and twelve months and less than six months, respectively.

\section{Settling of employment condition}

As shown in Figure 2, it appears the majority of respondents felt the employers determine workplace schedule $(74.4 \%)$, weekly working hours $(81.2 \%)$, and salary $(84.8 \%)$.

Figure 3 presents the degree of vulnerability of teachers in their respective schools. Overall, data reveals that the level of teachers' vulnerability is relatively low. For example, many teachers claim to have never been 
discriminated against (54.6\%), treated in a violent manner Figures 4 reveals that many teachers earn between 50000 (64.6\%), and afraid to demand better working conditions. and 1000000 Chilean pesos (57\%) while $20.2 \%$ earn over With respect to teachers' opinions about their salary. 1million Chilean peso.

\begin{tabular}{|c|c|c|c|c|c|c|c|c|c|c|}
\hline \multirow{2}{*}{$\begin{array}{l}\text { 1. Afraid to demand better working conditions } \\
\text { 2. Defenceless towards unfair treatment }\end{array}$} & $11.7 \%$ & $11.7 \%$ & \multicolumn{4}{|c|}{$39.0 \%$} & $6.7 \%$ & \multicolumn{3}{|c|}{$30.9 \%$} \\
\hline & $13.0 \%$ & $13.5 \%$ & \multicolumn{3}{|c|}{$25.6 \%$} & $11.2 \%$ & \multicolumn{4}{|c|}{$36.8 \%$} \\
\hline 3. Discriminatory and unjust treatment & $8.1 \%$ & $15.7 \%$ & 13.9 & \multicolumn{7}{|c|}{$59.6 \%$} \\
\hline 4. Authoritarian and violent treatment & $4.0 \%$ & $13.9 \%$ & $13.9 \%$ & & & & $64.6 \%$ & & & \\
\hline \multirow[t]{2}{*}{ 5. Feeling you can be easily replaced } & $14.8 \%$ & $7.6 \%$ & \multicolumn{3}{|c|}{$28.7 \%$} & \multicolumn{2}{|l|}{$21.1 \%$} & \multicolumn{3}{|c|}{$27.8 \%$} \\
\hline & $10 \%$ & $20 \%$ & $30 \%$ & $40 \%$ & $50 \%$ & $60 \%$ & $70 \%$ & $80 \%$ & $90 \%$ & $100 \%$ \\
\hline \multicolumn{11}{|c|}{ Only one time } \\
\hline
\end{tabular}

Figure 3. Perception of teachers regarding their degree of vulnerability in workplace

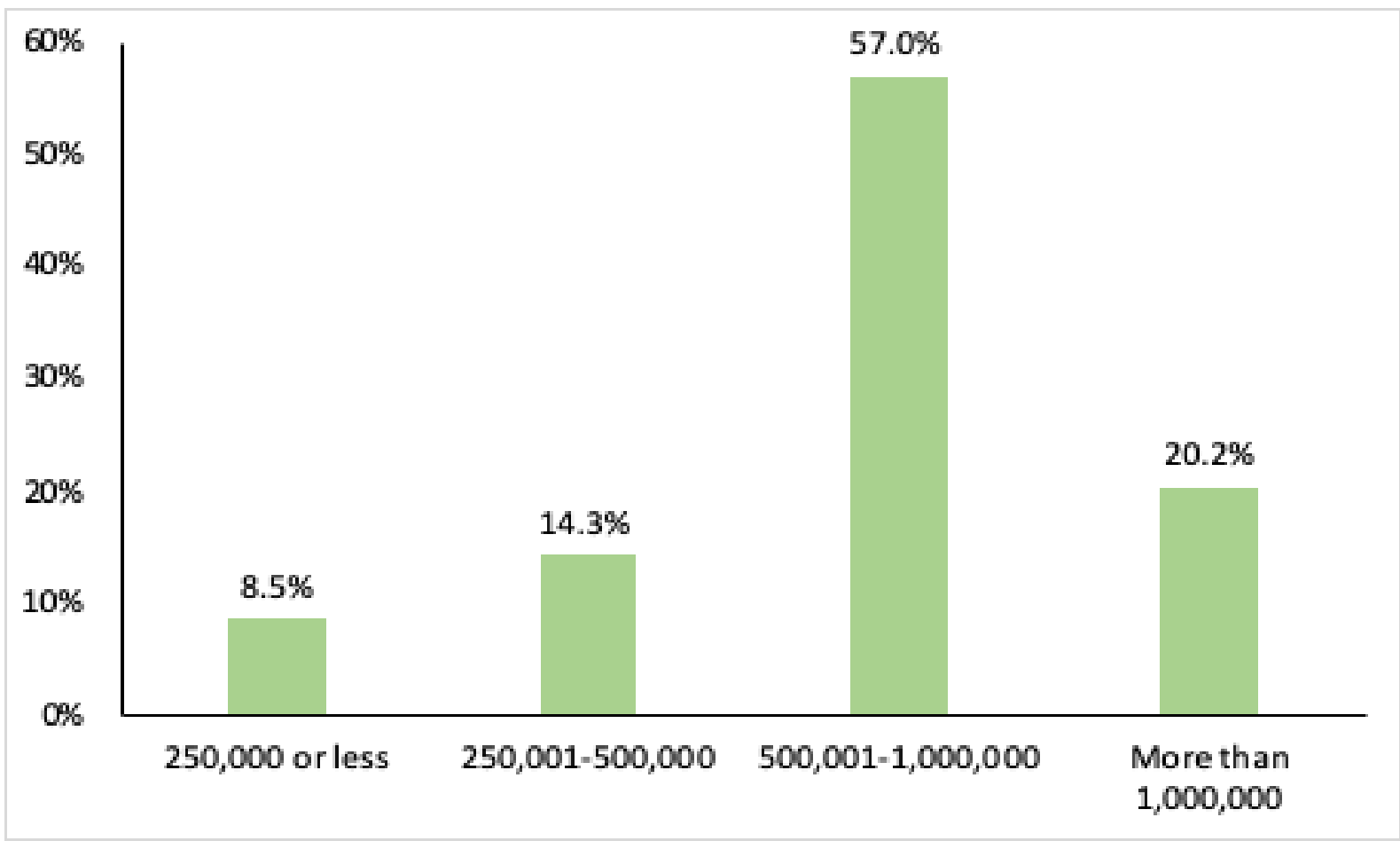

Figure 4. Overview of Chilean English teachers' earning 


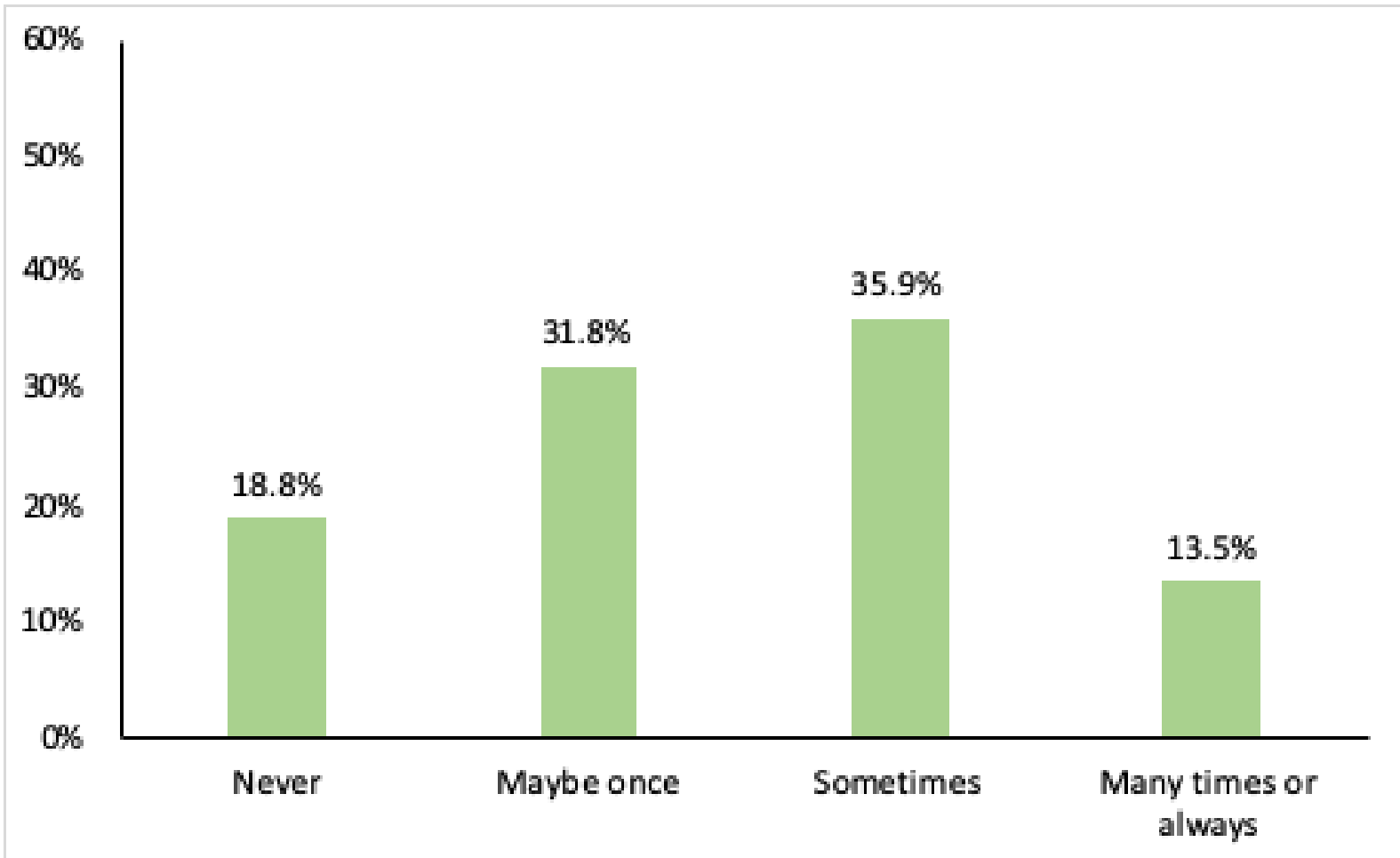

Figure 5. English teachers' view regarding the sufficiency of their salary in covering unexpected expenses

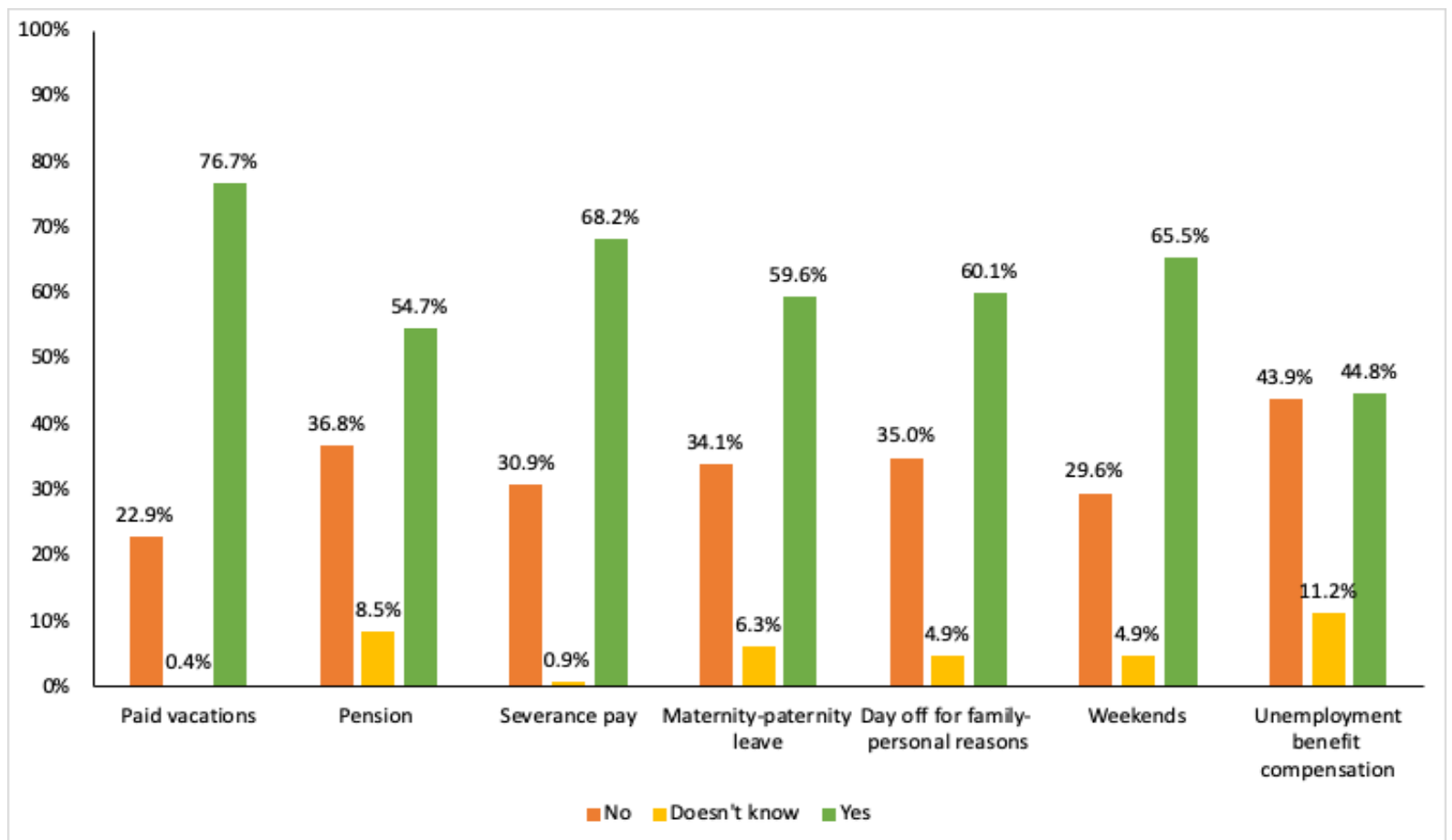

Figure 6. English teachers' perception of their basic rights in the workplace

From figure 5, we can see that a notable number of teachers $(35.9 \%)$ believe their salary sometimes cover their unexpected expenses

Figure 6 illustrates the level of rights that teachers have in their workplace. It is quite revealing that a significant percentage of teachers have access to their basic benefits such as a pension (54.7\%), severance pay (68.2\%), amongst others. However, half of the informants claim that they do not have access to unemployment benefits/compensation.

The results, as seen in figure 7 , indicate the extent to which teacher can exercise their fundamental right without 
obstacles. Overall, a considerable number of teachers can always take vacations and weekends. But surprisingly, less or fewer than $50 \%$ of teachers can always take sick leave, go to the doctor and request a day off for personal reasons without when necessary without facing an obstacle.

Figure 8 demonstrates the degree of respondents' agreement on several issues that are connected to precarious work. While many teachers agree that the type of employment contract influence their long term plan and that they often don't feel like going out in the evening because they are tired, a large number of them disagree with the notion of using students' evaluation as part of rehiring process and the fact that the teachers feel secure in their rehiring prospect albeit they are interested in the job.

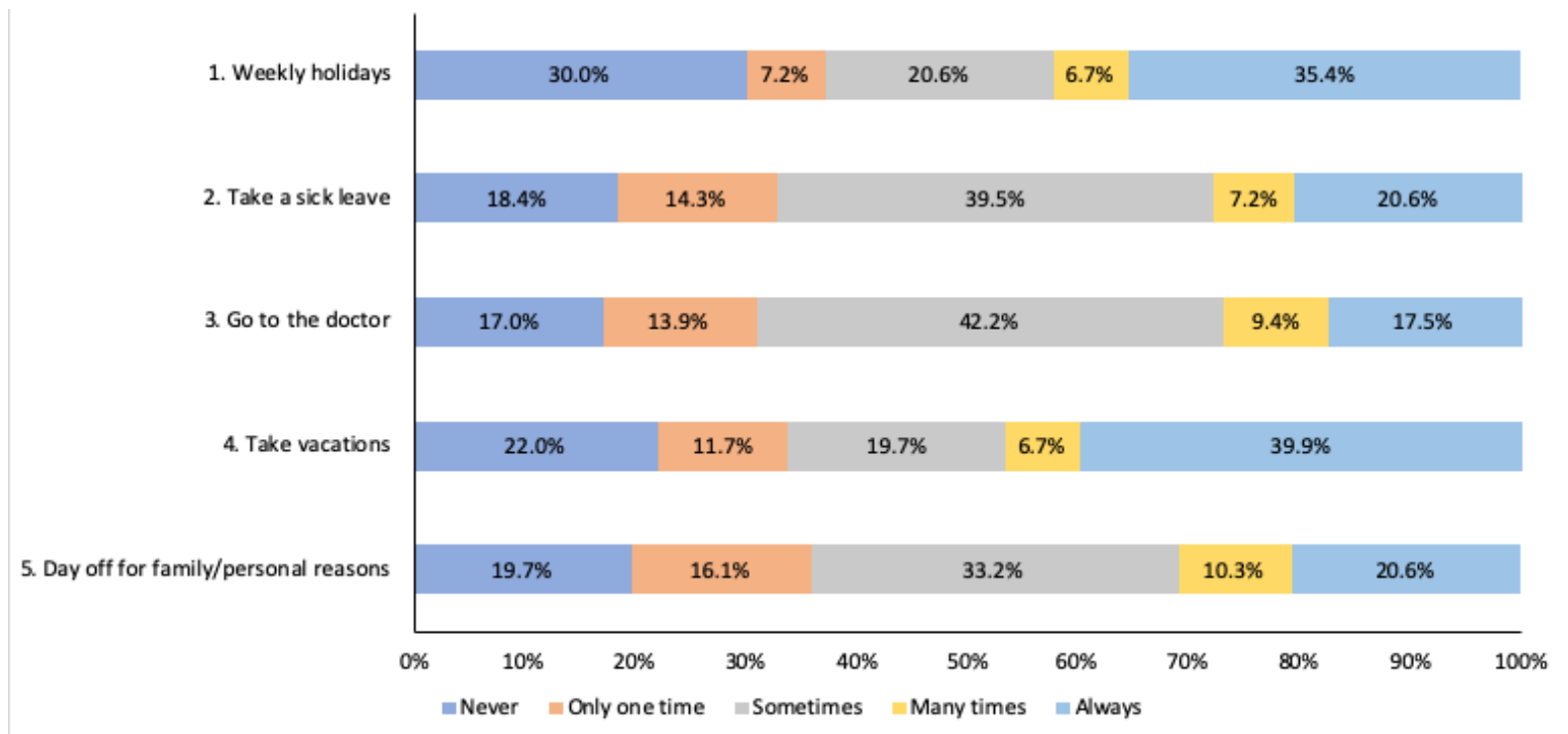

Figure 7. English teachers' perception of the extent at which they can exercise their rights without obstacles

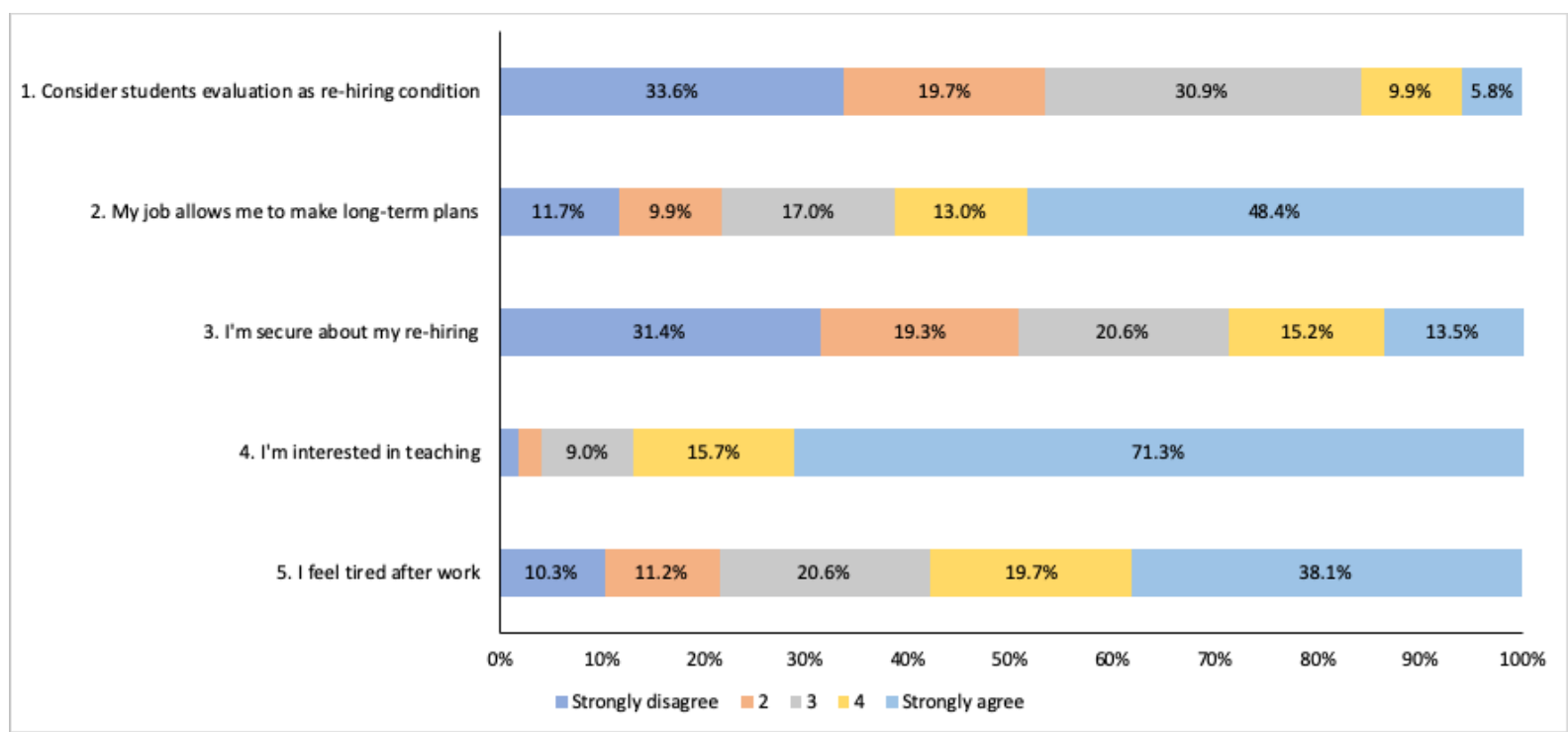

Figure 8. English teachers' perception on numerous issues 
Table 2 shows the overall degree of precarious employment in the industry and the level of reliability of the items used for the measurement. Considering that the lower the mean value, the higher the precariousness and vice versa. Thus, it can be seen from the table that the level of precariousness is slightly low, at 2.77 (EPRES total scale) at the total average of 4.17 Likert scale. On the other hand, the overall internal consistency stands at .640. Thus, the Cronbach alpha test of reliability can be considered to be adequate (Taber, 2018)

Table 3 shows the distribution of precarity in relation to gender, types of employment contracts, age, educational qualification, school curriculum taught by teachers, and feeling of job security. The level of precarity (2.48) and the sense of job insecurity (2.11) is higher among teachers with temporary contracts compares to their counterparts possessing permanent contracts. Although precarity is higher among teachers below 30 years old (2.64) than those above 30 years old (2.86), but there is no significant difference between both genders. Concerning educational qualification, the precariousness is higher among bachelor degree holders compares to those that possess masters and doctorate degree. Regarding the school curriculum, precariousness is highly ingrained in English institutes (2.22), followed by universities (2.70) and primary and secondary schools (2.79). Surprisingly, there is no significant difference between the two groups of the teacher regarding how the higher level of tiredness they feel after work.

Table 2. Degree of precariousness in Chilean English Language Teaching Industry

\begin{tabular}{ccccccc}
\hline & Items & Mean & SD & Min & Max & Cronbach's alpha \\
\hline Temporariness & 2 & 3.57 & 1.35 & 1 & 5 & .605 \\
Disempowerment & 3 & 1.36 & 0.55 & 1 & 3 & .568 \\
Vulnerability & 5 & 3.74 & 1.04 & 1 & 5 & .880 \\
Wages & 3 & 2.62 & 0.74 & 1 & 4 & .753 \\
Rights & 7 & 2.28 & 0.59 & 1 & 3 & .774 \\
Exercise rights & 5 & 3.06 & 1.15 & 1 & 5 & .851 \\
EPRES total scale & 25 & 2.77 & 0.57 & 1.29 & 4.17 & .640 \\
\hline
\end{tabular}

Table 3. Level of precarious employment across different variables

\begin{tabular}{|c|c|c|c|c|}
\hline Variables & Code & Types of variables & $\begin{array}{c}\text { Mean (standard } \\
\text { Deviation) }\end{array}$ & Significant Difference \\
\hline \multirow{2}{*}{ Gender } & 1 & Female & $2.74(0.55)$ & \multirow{2}{*}{ No Significant difference } \\
\hline & 2 & Male & $2.91(0.61)$ & \\
\hline \multirow{2}{*}{ Employment contracts } & 1 & Teachers with temporary contract & $2.48(0.48)$ & \multirow{2}{*}{$\begin{array}{l}\text { Significant difference } \\
\qquad(U=2149.00)\end{array}$} \\
\hline & 2 & Teachers with a permanent contract & $3.12(0.45)$ & \\
\hline \multirow{2}{*}{ Age } & 1 & Below 30 & $2.64(0.56)$ & \multirow{2}{*}{$\begin{array}{l}\text { Significant difference } \\
\quad(U=4689.50)\end{array}$} \\
\hline & 2 & Above 30 & $2.86(0.56)$ & \\
\hline \multirow{3}{*}{ Educational qualification } & 1 & TEFL certificate & $2.66(0.59)$ & \multirow{4}{*}{$\begin{array}{l}\text { No significant difference is } \\
\text { observed between } 1 \text { and } 2 \text {, } \\
\text { but there is a significant } \\
\text { difference between } 2 \text { and } 3\end{array}$} \\
\hline & 2 & Bachelor Degree & $2.73(0.54)$ & \\
\hline & 3 & Postgraduate Degree & $2.95(0.60)$ & \\
\hline \multirow{4}{*}{ School Curriculum } & 1 & Primary Schools & $2.79(0.55)$ & \\
\hline & 2 & Secondary Schools & $2.86(0.50)$ & \multirow{3}{*}{$\begin{array}{c}\text { The significant difference } \\
\text { of } 4 \text { with } 2 \text { and } 3 .\end{array}$} \\
\hline & 3 & Universities & $2.70(0.72)$ & \\
\hline & 4 & English Institutes & $2.22(0.43)$ & \\
\hline \multirow{2}{*}{ Feeling of job security } & 1 & Teachers with temporary contract & $2.11(1.25)$ & \multirow{2}{*}{$\begin{array}{c}\text { Significant difference }(U= \\
3499.00)\end{array}$} \\
\hline & 2 & Teachers with a permanent contract & $3.19(1.36)$ & \\
\hline \multirow[t]{2}{*}{ Tiredness after work } & 1 & Teachers with a temporary contract & $3.62(1.29)$ & \multirow{2}{*}{ No significant difference } \\
\hline & 2 & Teachers with a permanent contract & $3.66(1.43)$ & \\
\hline
\end{tabular}


Table 4 demonstrates the disparity in the dimensions of precarity between permanent and temporary contract teachers. While the degree of precariousness is significantly higher with respect to dimension of temporariness, vulnerability, wages, rights, and exercising of right among temporary contract teachers, there is no significant difference between the two groups of teachers regarding disempowerment.

Table 4. Comparing the degree of precariousness in different dimensions between permanent and temporary English teachers

\begin{tabular}{cccc}
\hline Type of contract & $\begin{array}{c}\text { Permanent } \\
\mathrm{M}(\mathrm{SD})\end{array}$ & $\begin{array}{c}\text { Temporary } \\
\mathrm{M}(\mathrm{SD})\end{array}$ & $U$ \\
\hline Temporariness & $4.64(0.74)$ & $2.69(1.06)$ & $645.00^{* * *}$ \\
Disempowerment & $1.38(0.56)$ & $1.35(0.53)$ & 6018.50 \\
Vulnerability & $3.87(1.08)$ & $3.63(1.00)$ & $5080.00^{*}$ \\
Wages & $2.91(0.66)$ & $2.37(0.71)$ & $3751.50 * * *$ \\
Rights & $2.50(0.42)$ & $2.09(0.65)$ & $3999.00 * * *$ \\
Exercise of rights & $3.42(1.07)$ & $2.76(1.13)$ & $4150.50 * * *$ \\
\hline
\end{tabular}

$\mathrm{M}=$ Mean; $\mathrm{SD}=$ Standard deviation.

$*=p<.05 ; * *=p<.01 ; * * *=p<.001$ (Schober et al., 2018)

\section{Discussion}

In reviewing the literature, no data were found on the level of precarity in the ELT industry in Chile. The current study found that more than $50 \%$ of English teachers are working under a temporary contract. In addition, the degree of precarity is higher among teachers working with temporary contracts compared with those holding permanent contracts. These results match those observed in an earlier study conducted in France (Wickam, 2015). In response to the question of why it is hard for most English teachers to secure a permanent teaching position, some reasons are based on the oversupply of teachers in elementary and middle schools. One of the focus group members illustrated as follows:

"In my municipal, we have an overpopulation of English teachers, and it's not just hard for us to get permanent jobs. It's also difficult for every single teacher that I have known".

This response agrees with our hypothesis on the possible cause of precarity. That is, the oversupplying of English teachers that is outweighing the demand for elementary and middle schools.

Other determining factors responsible for the problem are attributed to the quality of teachers' pedagogical skill. That is, the prospect of securing a permanent job is a function of teachers' skill. As one interviewee said:

"I think it's difficult because employers are constantly looking for more and more qualified teachers who are ideally young and innovative. It

\section{becomes hard to compete".}

A teacher also believes some private schools contribute significantly to the cause of the problem. The argument is that some schools are commercializing for profit gain, by hiring teachers temporarily so that they can avoid paying certain benefits. For example, one interviewee said. "some schools are business and they have become companies so they want to avoid a permanent employment contract so they just give jobs for 1 or 2 years and after that they Fire teachers and are not obliged to pay any compensation".

One unanticipated finding was the negative impact of teachers' job instability on students learning outcomes. One of the interviewees believes that most school principals understand the importance of having permanent teachers in their school. The informants argue that students have a better learning outcome when they are familiar with a teacher for a long time because it promotes the continuity of an effective and particular learning style.

Prior studies have noted the implication of an explicit form of precarity, which manifests itself as a form of imposition of a specific contract on employees (Forde \& slater, 2016). The results of this study show that salary, working schedule, and working hours are solely determined by the employer. Such a result might not necessarily mean disempowerment of teachers provided such teachers have the right to accept, reject, or negotiate the terms and conditions of the contract. However, many teachers attributed such an imbalance of rights to the fact that the system has already established such working conditions. As one interviewee put it:

"in my opinion, salaries should be determined by the State taking into consideration the quantity of experience, professional achievements, conditions inside the school, place, conditions of the characteristics of students, etc. all of the for municipalities and particular subvencionado".

On the other hand, an interviewee is not in support of this practice. It is widely believed that working schedule, hours and salary should be done collectively. This finding has an important implication in understanding teachers' attitudes and behavior towards the school as far as their employment contract is concerned.

A strong relationship between teachers' work stress and precarity has been reported in the literature (Lewchuk et al., 2005). This finding confirms the association between these two variables. Several possible explanations for teachers' stress can be linked to feeling of less important in schools (Bhandari \& Hesmati 2006) and to a situation of spending more time in searching for new employment and concurrently making effort to keep the job by seeking positive employer assessment of work (Lewchuk et al., 2005).

Two indicators that foster teachers' chances of securing permanent position are age and educational qualification were identified in this study. For example, precarious 
employment is higher among teachers below the age of 30 compared with those above 30 . Thus, the possibility of obtaining a permanent position increases with age and teaching experience. It is an indication that precarious employment is higher among early career teachers. Moreover, precariousness is higher among teachers with undergraduate degrees compare with their counterparts holding postgraduate degrees. Therefore, it can be argued that higher degree qualifications boost teachers' profiles for a permanent job.

Finally, considering a large number of teachers working under a temporary contract, this indicates that many teachers pass through the rehiring process every year or often. The discussion of how the rehiring process is carried out is critical for this study. It is revealed that many teachers disagree with the adoption of student evaluation as a primary metric for their rehiring. Most of the disagreements are anchored on the pedagogical deficit of students to assess their teachers fairly. As one interviewee stated:

"I don't agree with that because students are not empowered at all for evaluating a teacher, they are not adults, they could just have personal reasons and not professional criteria to assess a teacher. Besides schools should take into account that the age of the students is not appropriate for judging a teacher's work".

Rather than this approach, numerous respondents advocate for adoption of English proficiency test as the primary metric for rehiring teachers.

\section{Conclusion}

The purpose of the current study was to determine the degree of precariousness in the Chilean ELT industry. One of the significant findings to emerge from this study is that English teachers holding temporary contracts account for $56.8 \%$ of the teaching workforce in the industry. The second major finding was that in general, the degree of precariousness is higher among English teachers working in temporary contracts, including casual and substitute ones. In addition, a large percentage of teachers reported feeling stress after work, but the cause is not connected to the type of contracts they possess. Overall, our results showed that the level of precarious employment in the industry is slightly low. Drawing on the need to foster job stability for English teachers which is critical in making lifelong term goal plans and the importance of having more permanent teachers in schools to enhance stable learning styles and outcomes among students, one major suggestion offered by English teachers to the policymakers on how to increase permanent teaching positions is a modification of labor policy that provides teachers more opportunity to work more than one year. The findings from this study make several contributions to the discourse of precarity.
This is the first study reporting on precarious work in the Chilean ELT industry. Findings such as the salary offered in different school curricula will help English teachers in making informed decisions regarding salary negotiations. This finding has important implications for developing an instrument to assess the precarious employment of teachers in different educational disciplines. Periodical assessment is also recommended so that teachers can be making intermittent informing decision as far job search and salary negotiation is concerned. However, the findings in this study are subject to at least two limitations. First, the study did not use the complete stress tool to determine the disparity in the level of stress between permanent and temporary contract holders. Another major limitation is the low response rate $(8 \%)$ for the study recorded in the northern part of the country. Thus, more broadly research is needed to assess the different dimensions of work stress level that exists between the two groups of teachers.

\section{REFERENCES}

[1] Amable, M., Benach, J., Muntaner, C., Benavides, F. G., Gimeno, D., Menendez, M., ... \& Artazcoz, L. (2006). Psychosocial dimensions of precarious employment: Developing an epidemiological measure of work precariousness. La precariedad laboral y su impacto en la salud: Un estudio en trabajadores asaliardos en España, ed. M. Amable, 111-131.

[2] Amable, M. (2009). La precariedad laboral y su impacto sobre la salud. Un estudio en trabajadores asalariados en España [Job insecurity and its impact on health. A study in salaried workers in Spain]. Universitat Pompeu Fabra.

[3] Arnold, D., \& Bongiovi, J. R. (2013). Precarious, informalizing, and flexible work: Transforming concepts and understandings. American Behavioral Scientist, 57(3), 289-308.

[4] Banerjee, A., and Chaudhury, S. (2010). Statistics without tears: populations and samples. Ind. Psychiatry J. 19, 60-65. doi: $10.4103 / 0972-6748.77642$

[5] Barbier, J.C. 2002. A survey of the use of the term précarité in French economics and sociology. Document de Travail No 19. Retrieved from Paris.

[6] Benach, J., \& Muntaner, C. (2007). Precarious employment and health: developing a research agenda. Journal of Epidemiology \& Community Health, 61(4), 276-277.

[7] Berlant, L. (2011). Cruel optimism. The affect theory reader, 93-117.

[8] Berríos, P. (2015) La profesionalización académica en Chile: crecimiento y profesionalización [Academic professionalization in Chile: growth and professionalization], In Bernasconi (ed.), La Educación Superior de Chile. Transformación, Desarrollo y Crisis, Ediciones UC: $345-370$

[9] Bhandari, A.K. and Heshmati, A. (2006). Wage inequality 
and job insecurity among permanent and contract workers in India: evidence from organized manufacturing industries. Discussion paper 2097.

[10] Bourdieu, P. (1998). Acts of resistance: Against the tyranny of the market (R. Nice, Trans.). Cambridge: Polity Press

[11] Butler, J. (2004). Precarious life: The powers of mourning and violence. New York, NY: Verso.

[12] Byoung-Hoo, L. and Frenkel, S.J. (2004). Divided workers: social relations between contract and regular workers in a Korean auto company. Work, Employment and Society, 18, $507-530$.

[13] Colak, E. (2015). How the use of temporary employees affect standard and nonstandard employees' attitude and behavior towards organizations.

[14] Connelly, C.E. and Gallagher, D.G. (2004). Emerging trends in contingent work research. Journal of Management, 30, 959-983.

[15] Cooper, R., Chenail, R. J., and Fleming, S. (2012). A grounded theory of inductive qualitative research education: results of a meta-data-analysis. Qual. Rep. 17, 1-26.

[16] Courtois, A. D. M., \& O'Keefe, T. (2015). Precarity in the ivory cage: Neoliberalism and casualisation of work in the Irish higher education sector. Journal for Critical Education Policy Studies, 13(1).

[17] Creswell, J. W. (2009). Research design: Qualitative and mixed methods approaches. London and Thousand Oaks: Sage Publications.

[18] Employment Insurance. (2019, December 3). Employment Insurance Benefits. Retrieved from Employment Insurance: https://www.canada.ca/en/services/benefits/ei.html

[19] European Foundation for the Improvement of Living and Working Conditions. (2006). Fourth European working conditions survey. European Foundation for the Improvement of Living and Working Conditions.

[20] Forde C and Slater G (2016) Labour market regulation and the 'competition state: an analysis of the implementation of the Agency Working Regulations in the UK'. Work, Employment and Society 30(4): 590-606.

[21] Foucault, M. 2008. The birth of biopolitics: Lectures at the Collège de France. Basingstoke: Palgrave Macmillan.

[22] Frade, C., Darmon, I., \& Laparra, M. (2004). Precarious employment in Europe: A comparative study of labour market related risk in flexible economies. Esope Project, European Commission, available at $<$ http:/lec. europa. eu/research/social-sciences/pdf/finalreport/hpse-ct-2001-00 075-final-report. pdf>(last access 2020, February).

[23] Hernández, R., Fernández, C., \& Baptista, P. (2010). Metodología de la investigación (5ta. ed.). México DF.

[24] Holden, R. B. (2010). "Face validity" in The corsini encyclopedia of psychology. 4th Edn. eds. I. B. Weiner and W. E. Craighead Hoboken (NJ: Wiley).

[25] Jain, A., \& Hassard, J. (2014). Precarious work: definitions, workers affected and OSH consequences. https://oshwiki.eu/wiki/Precarious_work:_definitions,_wor kers_affected_and_OSH_consequences
[26] Jenkins, K. A., Charteris, J., Bannister-Tyrrell, M., \& Jones, M. (2017). Emotions and Casual Teachers: Implications of the Precariat for Initial Teacher Education. Australian journal of teacher education, 42(12), 162-179.

[27] Kerr, P., \& Wickham, A. (2017). ELT as an Industry. Retrieved 15 September 2020, from https://adaptivelearning inelt.wordpress.com/2017/02/15/elt-as-an-industry/

[28] Lasekan, O.A. (2019). How well prepared are Chilean beginning English teachers to meet job demands in English language teaching industry? Journal of Entrepreneurship Education, 22(6).

[29] Lewchuk, W. (2016). The precarity penalty: How insecure employment disadvantages workers and their families. Alternate Routes: A Journal of Critical Social Research, 27.

[30] Lewchuk, W., de Wolff, A., King, A. and Polanyi, M. (2005). Beyond job strain: employment strain and the health effects of precarious employment. Work in a global society. Working paper series, 2005-1, Labour Studies Programme, McMaster University.

[31] Lincoln, Y. S., \& Denzin, N. K. (Eds.). (2000). Handbook of qualitative research (pp. 163-188). Thousand Oaks, CA: Sage.

[32] List, D. (2004). Maximum Variation Sampling for Surveys and Consensus Groups. Adelaide, Australia: Audience Dialogue.

[33] Lopes, A., \& Dewan, I. (2014). Precarious pedagogies? The impact of casual and zero-hour contracts in higher education. Journal of Feminist Scholarship, 7(8).

[34] McCormack, D., \& Salmenniemi, S. (2016). The biopolitics of precarity and the self. European Journal of Cultural Studies, 19(1), 3-15.

[35] McCormack, A., \& Thomas, K. (2005). The reality of uncertainty: The plight of casual beginning teachers, Change: Transformations in Education. 8(1), 17 - 31 .

[36] McLean Parks, J., Kidder, D.L. and Gallagher, D.G. (1998) Fitting square pegs into round holes: mapping the domain of contingent work arrangements onto the psychological contract. Journal of Organizational Behavior, 19(Special issue), 697- 730 .

[37] Millar, K.M. 2017. Towards a critical politics of precarity. Sociology Compass 11, no. 6: e12483.

[38] Mindzak, M. (2016). Exploring the Working Lives of Unemployed and Underemployed Teachers in Ontario (Unpublished Thesis). University of Western Ontario, London, ON

[39] Neilson, B. \& N. Rossiter 2008. Precarity as a political concept, or, Fordism as exception. Theory, Culture \& Society 25(7-8), 51-72.

[40] Percy, A., \& Beaumont, R. (2008). The casualisation of teaching and the subject at risk. Studies in Continuing Education, 30(2), 145-157.

[41] Puig-Barrachina, V., Vanroelen, C., Vives, A., Martínez, J. M., Muntaner, C., Levecque, K., ... \& Louckx, F. (2014). Measuring employment precariousness in the European Working Conditions Survey: the social distribution in Europe. Work, 49(1), 143-161. 
[42] Quinlan, M. (2016). Precarity and workplace well-being: A general review. In Safety or Profit? (pp. 29-44). Routledge.

[43] Quiñones, M., Van den Broeck, A., \& De Witte, H. (2012). Burnout en profesores. Revista Chilena de Salud Pública, 16(3), 212-224.

[44] Schober, P., Boer, C., and Schwarte, L. A. (2018). Correlation coefficients: appropriate use and interpretation. Anesth. Analg. 126, 1763-1768. doi: 10.1213/ANE.000000 0000002864

[45] Simbürger, E., \& Neary, M. (2016). Taxi Professors: academic labour in Chile-a critical practical response to the politics of worker identity. Workplace: a journal for academic labour, 28, 48-73.

[46] Standing, G. (2011). The precariat: The new dangerous class (Londres, Bloomsbury Academic).

[47] Taherdoost, H. (2016). Sampling methods in research methodology: how to choose a sampling technique for research. IJARM 5, 18-27. doi: 10.2139/ ssrn.3205035

[48] University and College Union (Great Britain) (UCU). (2016). Precarious Work in Higher Education: A Snapshot of
Insecure Contracts and Institutional Attitudes. http://hdl.voced.edu.au/10707/417847.

[49] Vives, A., Amable, M., Ferrer, M., Moncada, S., Llorens, C., Muntaner, C., ... \& Benach, J. (2010). The Employment Precariousness Scale (EPRES): psychometric properties of a new tool for epidemiological studies among waged and salaried workers. Occupational and environmental medicine, 67(8), 548-555.

[50] Vives-Vergara, A., González-López, F., Solar, O., Bernales-Baksai, P., González, M. J., \& Benach, J. (2017). Precarious employment in Chile: psychometric properties of the Chilean version of Employment Precariousness Scale in private sector workers. Cadernos de saude publica, 33, e00156215.

[51] Walsh, P. (2019). Precarity. ELT Journal, 73(4), 459-462.

[52] Wickham, A. 2015. My tailor is not rich: a report on the teaching conditions in France'. Teaching Times (TESOL France) 73:9-12

[53] Zeytinoglu, I.U., Lillevik, W., Seaton, M.B. and Moruz, J. (2004). Parttime and casual work in retail trade. Stress and other factors affecting the work- place. Industrial Relations, $59,516-544$. 